


\title{
Abenomics: HaS IT WORKED? WILL IT FAIL?
}

\author{
Sébastien Lechevalier and Brieuc Monfort
}

N6 | DECEMBER 2016

\section{THE AUTHORS}

Sébastien Lechevalier is a Professor at the EHESS, President of Fondation France Japon de l'EHESS (http://ffj.ehess.fr) and Director of the French Network for Asian Studies (http://www.gis-reseau-asie.org).

Contact: sebastien.lechevalier@ehess.fr

Brieuc Monfort is Associate Researcher at the Center for French-Japanese Advanced Studies (CEAFJP, Paris).

\section{Abstract}

Abenomics initially generated high expectations but it has more recently come to be seen as yet another failed economic experiment. Yet discussion of Abenomics often verges on caricature. It is thus crucial to provide a critical and balanced evaluation. We argue that, over the past four years, the proactive policies pursued under Abenomics have played a decisive role in reversing one cause of the Japanese slowdown - inconsistent economic policies - and that they are now yielding preliminary results. We are more critical in regards to long-term issues: as the case of trade policy shows, the problem is not so much a lack of structural reform as limits to its ability to increase Japan's growth potential.

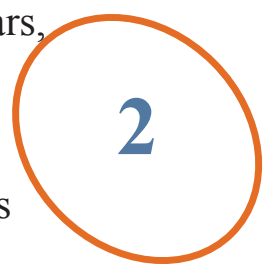

\section{KEYWORDS}

Monetary policy, fiscal policy, structural reforms, deflation, Japan

\section{AUTHOR'S RECENT PUBLICATIONS}

- Lechevalier, S., and B. Monfort, Leçons de l'expérience japonaise. Vers une autre politique économique?, Collection du CEPREMAP n 41, Paris: Editions Rue d’Ulm, 2016.

--Lechevalier, S. (ed.), The Great Transformation of Japanese Capitalism, London: Routledge, 2014. 


\section{TABLE DES MATIĖRES}

1. Introduction 4

2. Abenomics: An economic and political project 5

2.1 The economy in the service of a political project

2.2 Abenomics and debate over the Lost Decade(s)

2.3 Three breaks with the past

3. Implementing the three arrows

3.1 Exiting deflation

3.2 Fiscal stimulus and fiscal consolidation

3.3 Choosing from a menu of structural reforms

4. Short-term impact of Abenomics

4.1 A tentative exit from deflation

4.2 An erratic growth performance

5. Why Abenomics may fail

5.1 The limits of structural reforms

5.2 Beyond the structural reform view: An institutionalist perspective

6. Conclusions 
Abenomics: relying on quarterly results in the absence of a broader view, this perspective is reflected in extreme (positive or negative) evaluations.

The purpose of the present article is to provide a critical but non-normative evaluation of the first four years of Abenomics that seeks to move beyond the aforementioned limitations. We shall seek to answer the following questions: Is Abenomics the right economic policy recipe to boost growth in Japan? How are its results to be assessed after roughly four years of implementation? To this end, we adopt the following methodology, centered on three main choices:

\section{INTRODUCTION}

At its inception, Abenomics was heralded as a radically new economic policy. Four years later, the set of policies promoted and implemented by Prime Minister Shinzo Abe are more often derided as yet another failed economic experiment. Given the pervasively critical manner in which Abenomics is now seen, it is easy to forget the fact that it was initially embraced by many economists. In early 2013, one economist even argued with deliberate exaggeration that Abenomics was the first significant event to happen in Japan since the bubble burst. Early skeptics such as Ryutaro Kono, chief economist at BNP Paribas, and Hiroshi Yoshikawa, a professor at Rissho University, now insist on their foresight in predicting that Abenomics was bound to fail.

There is nothing unusual about differences of opinion among economists. Yet many conventional views regarding Abenomics verge on caricature. Promoters of these policies, first and foremost Abe himself, promised that they would resolve all lingering economic issues and put Japan "back on its feet" again. Critics, meanwhile, warned that Abenomics would lead to "Abegeddon" an inflationary spiral in which rising long-term interest rates would result in a combination of sovereign, banking and external crises.

In this context and given the high expectations for Abenomics, a critical and balanced evaluation of its results is crucial. In what follows, we argue that both over-optimistic and over-pessimistic predictions have been wrong for the following reasons: some predictions were theoretically well-grounded but disconnected from Japan's economic and political-economic context; others were too closely entwined with Japanese reality and excessively influenced by evaluations of the controversial figure of Abe, failing in this way to sufficiently consider quantitative data or define criteria of objective evaluation. "Short-termism" is another problem that commonly afflicts discussions of
Borrowing from various economic theories, we offer an "agnostic" evaluation based on standard economics. We believe that it is necessary to take an eclectic approach, especially given that Abenomics itself is of diverse inspiration (albeit strongly influenced by particular economists and theoretical viewpoints). We also remind the reader of Abenomics' initial objectives (e.g., exiting deflation) and timeline in order to establish precise evaluative criteria.

We take into account the Japanese economic and political-economic context of the past 25 years as well as the political agenda of Abe himself. In doing so, we seek to avoid (e.g., political) determinism in order to offer an evaluation that is "situated" in this particular context. Abenomics is indeed difficult to understand without reference to economic history. For example, current debates regarding the effectiveness of the monetary policy of Governor Kuroda or the 2014 VAT increase must take into account respectively the effect of Quantitative Easing since 1999 or the 1997 VAT increase. Our intention is to avoid the kind of evaluations that are often prepared in offices far from the field. We believe that the duty of economists is to look at the reality and take several contextual elements into account. This means that the same set of policies cannot be evaluated in the same way from one geographical and historical context to the next: economic mechanisms vary in time and space and a given economic policy may lead to very different results in different environments (Boyer and Saillard, 2001). We will thus dramatically depart from mainstream analyses that see Japan in terms of arthritis (see, for example, Lincoln 2001), just as Europe was seen as suffering from "eurosclerosis" in the late 1990s. In our view, one may at once be an economist, employ the tools of the discipline and address a wider audience.

Being eclectic does not mean that ours is a purely "objective" or somehow theory-free evaluation. Throughout this paper, we bring a structuralist and institutionalist perspective to bear on our discussion of this experiment in economic policy. 
We draw three main conclusions. First, Abenomics has yielded encouraging results in some areas (e.g., exiting deflation), even though economic growth has fallen short of initial expectations. Second, Abenomics constitutes a qualified innovation. This finding runs contrary to the received wisdom (see, for example, Hoshi 2013), according to which the monetary policy of Abenomics deserves a grade of "A" but structural reforms only a grade of "F"'. The major novelty of Abenomics resides, not just in its monetary policy, but also in the manner in which different economic policy tools with different time horizons have been coordinated. It is an attempt, in other words, to bundle together different policy instruments in order to provide greater policy consistency and more efficient implementation via a clearer prioritization of goals and a more binding agenda. In marked contrast with the perception that politicians are unable to deliver results or implement policies in keeping with electoral campaign promises, Abenomics offers a de facto example of proactive policy-making. However -and this is our third finding - Abenomics may ultimately fail to the degree that, as our structuralist and institutionalist perspective suggests, it has underestimated some causes of Japanese stagnation such as inequality.

The remainder of this paper is organized as follows. The second section presents the general context of Abenomics while the third describes the implementation of the key measures announced during the electoral campaign. The fourth section evaluates what has worked and what has not worked so far. The fifth section explains why Abenomics may eventually fail if it does not take into account key impediments to growth in the Japanese context. A final section presents our conclusions.

\section{Abenomics: An eConomic and political PROJECT}

This section puts Abenomics into context both in regards to the overall political objectives of the Abe government and relative to previously implemented economic policies. Abenomics is in many respects innovative, especially in the context of Japanese policymaking. It would be an exaggeration, however, to call it revolutionary.

\subsection{THE ECONOMY IN THE SERVICE OF A POLITICAL PROJECT}

The fact that Abe, a graduate in political science from Seikei University, has given his name to a set of economic policies has surprised many observers since nothing about his first term as Prime Minister (20062007) suggested an interest in economics. Since 2012,

1 See, for example, Paul Krugman's (2013) glowing comments: "What is truly remarkable about Abenomics - the combination of a budgetary and monetary stimulus - is that no other advanced economy is trying anything similar." his intuition has led him to take the aspirations of ordinary Japanese citizens into account, focusing on economic recovery before seeking to achieve his own political agenda. The latter may be classified among the most nationalist within the Liberal Democratic Party (LDP), with priority given to revising the Constitution, defense policy, education and other areas in an effort to draw the curtain to a close on the post-war period (Lucken et al., 2014) and once again return Japan to the status of a "normal" country (Abe, 2007).

During the 2012 election campaign, these nationalist elements were clearly in evidence in Abe's program, whose slogan was "Put Japan back on its feet". Economic policy of course constituted an important part of this program. It also highlighted Japan's intention to join negotiations for the Trans-Pacific Partnership Agreement (TPP), which goes beyond strictly trade and economic issues, and the gradual resumption of operations at the nuclear power plants suspended in the wake of the Fukushima nuclear accident. In sharp contrast with the Democratic Party of Japan's (DPJ) 2009 program, which emphasized redistribution, these measures have generally tended to prioritize economic growth.

It is certainly ironic that Abenomics should receive such strong support from liberal economists in the United States such as Paul Krugman and those in Europe who promote economic alternatives to austerity policies as neither group would on the face of it be inclined to endorse the nationalistic and conservative aspects of Abe's policy. However, there is no schizophrenia in Abe's agenda. Abenomics aims at ending what is seen as the relative economic decay of Japan; this is a pre-condition for affirming Japanese power in all areas. The quest to once again become an economic giant, in other words, is supposed to help Japan overcome what is often seen as a secondary political role in international relations.

Having said that, one may nonetheless identify potential contradictions between Abe's nationalist and economic agendas. This appears most clearly in the relationship with China and South Korea. On the one hand, the economies of Japan and South Korea have benefited more than any others from China's growth since the 1990s (Ito and Hahn, 2010). On the other hand, Abe's nationalism is deeply hurting the relationship with these two countries and may in the mid-term be detrimental to the very success of Abenomics. While tensions with China and South Korea first emerged prior to Abe's second mandate, they also contributed to his return as head of his party in September 2012 and his subsequent victory in elections in December of that year. After two years marked by no high-level meetings, these initial tensions are gradually easing. In 2015, the leaders of Japan, China and South Korea cautiously resumed their 
meetings. However, major sources of diplomatic conflict remain and may once again become problematic in the near future. It is therefore necessary to take them into account in evaluating the likelihood that Abenomics will prove successful.

\subsection{Abenomics and debate over the Lost Decade(s)}

Given the apparent precedence of politics over economics in Abe's agenda, it is important to understand the intellectual origins of Abenomics. During his years in the wilderness - from the end of his first term in 2006 to his return to power six years later - Abe consulted a number of experts in economic policy, themselves participants in debates regarding the appropriate economic policies for Japan. Koichi Hamada, a professor of economics at Yale University, is usually credited for creating the portmanteau "Abenomics" and is thought to have been at the origin of recommendations to further pursue non-conventional monetary policy. Hamada supplied Abe with a window on American debates regarding Japanese economic policy. In some key respects, it is clear, Abenomics was influenced by the work of economists such as Paul Krugman.

In our view, it is difficult to understand Abenomics without referring to the consequences for Japan when the bubble burst in the early 1990s and the policy choices that followed it. Torn between conflicting analyses of the causes of Japanese economic slowdown over the past twenty-five years, Abenomics sometimes attempts to strike a balance between contradictory assessments. At other times, however, it clearly takes sides. While Abe's economic policies have challenged conventional debates on economic policy in Japan they may also be of broader resonance: should the focus be on policies supporting domestic demand (at the risk of worsening public debt) or should it be on supply-side policies with a potentially recessive impact over the short term? Are the main sources of deflationary pressure real factors or monetary ones? Should the government consolidate public finances given the high level of debt or on the contrary implement fiscal stimulus to support domestic demand?

The initially warm welcome extended Abenomics by most academic economists may in part be explained by the fact that it embraced long-standing views regarding the causes of the Japanese slowdown and took decisive steps in its efforts to address these shortcomings (with a grain of caution, see the reactions in Ito, 2014, or Bernanke, 2015, for example). Market economists remain more critical, especially those dealing with fixed income rather than equity. What must be underscored is that, by the early 2010s, there was not yet a clear consensus as to the causes of Japanese stagnation since the early 1990s. While some explanations emphasize short-term reasons - policy mistakes, for example, particularly in the area of monetary policy (see, for example, Bernanke, 2000; Krugman, 1998; Koo, 2003; or Ito and Mishkin, 2004) - others focus on structural factors such as the end of catch-up areas, an aging population and the lingering effects of the financial crisis provoked by the "bubble" (see, for example, Motonishi and Yoshikawa, 1999; Yoshikawa, 2002; Hoshi and Kashyap, 2011; or Cargill and Sakamoto, 2008). As Wakatabe (2015) has argued, the second category of explanations has achieved dominance over the past fifteen years. Hayashi and Prescott (2002) are an example of this shift from short-term factors in the first decade of the Japanese slowdown after the bubble burst to structural factors in the second decade of the slowdown. Nonetheless, the debate was far from over when Abe once again became Prime Minister in late 2012. This is one reason why Abenomics may be interpreted as an economic policy based on a tentative synthesis of these different explanations, leading it to be praised by economists as disparate as Krugman, Hoshi and Kashyap.

A recent book on Japan's economic history since the "bubble" (Lechevalier and Monfort, 2016) revisits the past twenty-five years with a focus on the policies that have been implemented to address the financial crisis, deflation, and slowing growth. The authors have two principal goals: on the one hand, they seek to explain how a run-of-the-mill, mainly financial crisis

came to be associated with a prolonged downturn over several years; on the other, they attempt to understand the policy choices and constraints faced by Japanese policymakers.

Lechevalier and Monfort (2016) contrast some common beliefs regarding Japanese economic performance over the past twenty-five years. Given the diversity of the period in question, there is no basis for claiming that Japan has experienced "two lost decades". Nor is the Japanese slowdown a result of political paralysis reflected in the absence of structural reforms. In their view, Japan's track record in implementing a structural reform agenda is in fact broadly similar to that of other industrialized economies (figure 1). Besides, the emphasis on structural reform is somehow selfvalidating: since there is no growth, the argument goes, this must be due to the absence of reforms. 


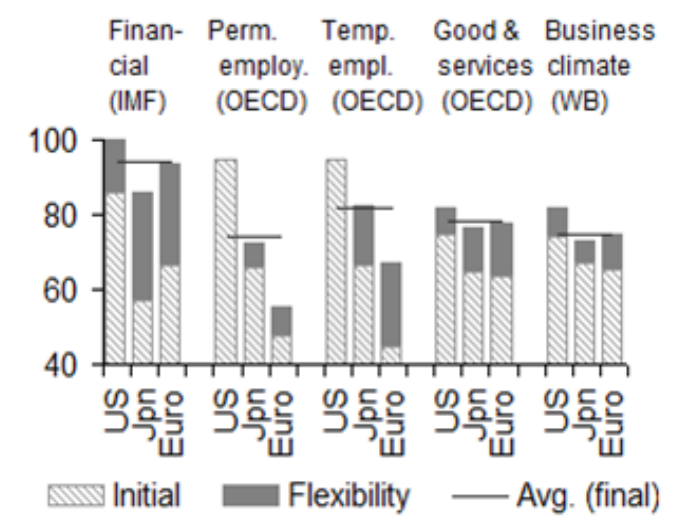

Degree of liberalization (from 0 to 100).

Initial state: shaded area (ex. 1990);

increase: dark grey (ex. from 1990 to 2005).

Sources : OECD ; IMF; World Bank.

Figure 1: Structural reforms in Japan, the United States, and Europe

Nor can the growth slowdown be explained in terms of the increasing divergence between an export-oriented industrial sector and a domestic-oriented service sector since, within both sectors, the productivity of firms has increased, a fact that has also contributed to labor inequality (Ito and Lechevalier, 2009). Indeed, the spread of innovation (from the most performing to the least performing firms) declined during this period as traditionalinstitutionalmechanisms-suchasthediffusion of innovation from large firms to their subcontractors - weakened (Lechevalier, 2014). Similarly, the impact of low growth on tax revenues, growing public debt and worsening labor market conditions - as evidenced, not by the rate of unemployment, but by the growing dichotomy between regular and non-regular workers - puts paid to the notion that there might be such a thing as "happy stagnation" (i.e., the claim that low growth has little negative impact on society). Finally, the notion that "deflation" is somehow good (deflation rightfully corrects excessive price levels) is also a myth as demonstrated by the difficulty in exiting deflation and the negative impact of deflation on the banking sector and economic activity, more generally.

So what really went wrong? Lechevalier and Monfort (2016) argue that the Japanese slowdown resulted from the conjunction of three main factors: a financial crisis that, after much delay, was acknowledged and resolved; a succession of exogenous or endogenous shocks to which countercyclical policies imperfectly responded; finally, a slowdown in growth that, on the supply side, reflected the end of the catch-up period and, on the demand side, resulted from the cumulative impact of the first two factors. In a context of increasing heterogeneity of performance, diminishing technological and organizational spillover between firms also contributed to the slowdown at the microeconomic level.
In contrast to other advanced economies more directly exposed to the Lehman shock, by the time Abe became Prime minister in 2012, banking problems - one of the main causes behind the "lost decade" of the 1990s were no longer relevant. However, policy responses and structural issues continued to command attention.

\subsection{THREE BREAKS WITH THE PAST}

Drawing lessons from the past, the economic policies that Abe has implemented since December 2012 diverge from earlier policies in three ways: economic policy became the main priority of government action (notwithstanding the importance of the political agenda, as mentioned earlier); all three instruments of economic policy were implemented simultaneously and in a coordinated manner; finally, monetary policy was given a new direction. Although it clearly breaks with the practice of Abe's predecessors, Abenomics does not in our view constitute a revolution in economic policy when compared to the policies implemented by other OECD countries.

One of the first respects in which Abenomics broke with the past was its prioritization of economic action, even though economics is mainly seen as a means to a political end in Abe's thought. Earlier prime ministers tended to focus on more narrow concerns or to concentrate on extra-economic matters. Keizo Obuchi (1998-2000) and Taro Aso (20082009), for example, focused on fiscal stimulus; Yukio Hatoyama was distracted by renegotiating the status of U.S. military bases in Japan (2009-2010); Naoto Kan and Yoshihiko Noda (2010-2012), for their parts, devoted most of their energy to raising the consumption tax and redefining energy policy in the wake of the 2011 earthquake. Apart from Abe, only two prime ministers have in the past two decades pursued wider programs centered on the economy: Ruytaro Hashimoto (1996-1998), whose five-pronged program included financial liberalization, fiscal consolidation, administrative reform and central bank independence; and Junichiro Koizumi (2001-2006), who restructured the banking sector (initially presenting it as an "antideflationary strategy"), sought to improve public finances (a program abandoned in 2002) and reformed the post office, local government (2003) and pensions (2004) (Tiberghien, 2014).

As noted earlier, during his first term from 2006 to 2007 - a time of economic recovery - Abe himself principally focused on foreign policy and reforming the Constitution. The latter remained important to Abe but, given voters' concerns about the economy, it was on this issue that he focused during the 2013 and 2014 elections. Over the past two years, Abe's popularity has been over $45 \%$, a rare feat that has been matched by only one of his predecessors, Prime Minister Koizumi (Figure 2). At the same time, his popularity rating has 
fluctuated, declining with each of his initiatives for constitutional reform or civil liberties and recovering when he again turned his attention to the economy. The importance given the economy is also illustrated by the creation - or revival - of three main advisory bodies: the Council of Economic and Fiscal Policy (CEFP), which Abe regularly attends, the Council on Industrial Competitiveness (CIC) and the Council for Regulatory Reform (CRR). Abe has benefited from reforms carried out by his predecessors, including the centralization of decision-making under the Prime Minister's authority, a measure crafted by Hashimoto and first successfully implemented by Koizumi.

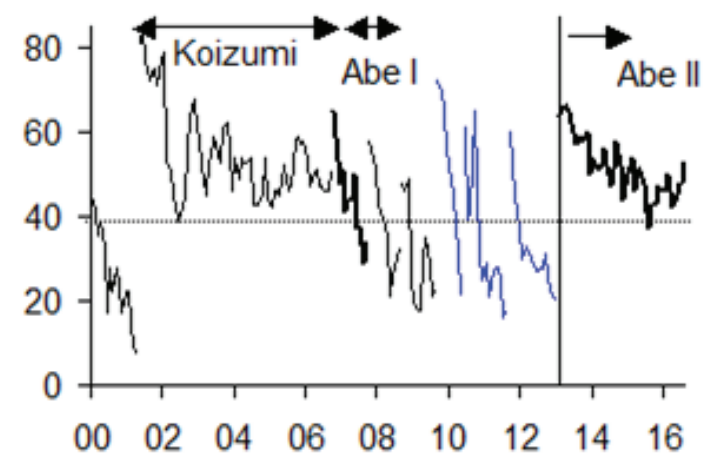

Source: NHK. Black and blue lines represent
respectively prime ministers from the LDP and
the DPJ. Bold dark lines represent Shinzo Abe.

Figure 2: Approval rating of Japanese Prime Ministers (in \%, 2000-2016)

Coordination of the three pillars (the "three arrows") of economic policy - a "flexible" fiscal policy, a "bold monetary policy" and a growth strategy based on private sector investment - constituted a second break with the policies of the past. Formerly, the three pillars had often been employed independently of one another and sometimes even in contradictory fashion. For example, under the governorship of Masaaki Shirakawa (20082013), the Bank of Japan defended the notion that the main causes of deflation were beyond the control of monetary policy. On this view, the implementation of structural reforms and fiscal consolidation were preconditions for a more active monetary policy, which would otherwise lead to debt monetization. Abenomics, by contrasts, insists on the fundamental complementarities between the various dimensions of economic policy, with priority given to the return of growth in a deflationary environment.

While not revolutionary, the implementation of the three arrows is innovative in the Japanese context. Monetary and fiscal policies are sometimes presented as policies aimed at gaining time before structural reforms boost the potential growth rate and Abe recognized that the success of his long-term strategy depended on potential growth. Coordination of the two countercyclical policies was facilitated by the calendar and the fact that the governor of the Bank of Japan would be reaching the end of his mandate in March 2013. Four months after the formation of the government, Haruhiko Kuroda, a former senior Ministry of Finance official and President of the Asian Development Bank, was nominated to succeed Shirakawa as head of the Bank of Japan.

The final and third respect in which Abenomics constitutes a break with the past is its embrace of a new monetary policy. Since gaining independence in 1997, the Bank of Japan has been led by three governors - all career officials from the central bank and maintained a high degree of managerial continuity. The Bank managed to maintain financial stability in a difficult environment marked by multiple economic and financial crises (2001 dot-com bubble, 2008 Lehman shock, 2011 earthquake). Despite this successful track record of maintaining financial stability, the central bank regularly fell short of its inflation objective, in part due to an overly cautious monetary policy.

The limited monetary policy actions undertaken before Abenomics have long been criticized by economists, both in Japan and abroad (Ito, 2004; Hamada, 2004; Krugman, 1998; Bernanke, 2000). Even some scholars who are cautious regarding the effectiveness of monetary policy admit that a more proactive policy might have added a few decimals of growth (Hoshi and Kashyap, 2011; Ueda, 2012).

While many economists advocated a change of monetary policy, Abe was willing to go well beyond their recommendations. During the 2012 campaign, he proposed raising the inflation target from 2 to $3 \%$, revising the Organic Law of the Bank of Japan and allowing direct central bank financing for public investment. These measures would have affected the de facto independence of the central bank. As prime minister, he also put direct pressure on the central bank in the first quarter of 2013. Eventually, this more radical aspect of Abe's economic vision was not implemented since the calendar allowed him to appoint Kuroda as governor in April 2013. Otherwise, there might well have been institutional reform to ensure that central bank policy was more in line with the views of the Prime Minister.

Thus, while Abenomics has in a number of respects proven innovative compared to earlier policies, it in is some ways merely a return to better macroeconomic policy coordination and is broadly consistent with the recommendations made by a large number of economists following the Lehman shock (Blanchard et al., 2012). The fiscal and structural components of Abenomics are also conventional from the point of view of their design. Growth policy, in particular, has many 
points in common with the growth strategies advocated by a number of previous administrations, although it significantly departs from them in terms of the initial effort that was invested to effectively implement these measures.

\section{IMPLEMENTING THE THREE ARROWS}

More than just a marketing ploy, the "three arrows" have taken some twists and turns over the past four years. In this section, we focus on the manner in which these measures have been implemented, a question that should also have a place in our evaluation exercise.

\subsection{EXITING DEFLATION}

Even before Abe's election in December 2012 and the appointment of a new governor to the Bank of Japan in March 2013, the expectation that monetary policy would be drastically changed contributed to the depreciation of the Yen and growth in the stock market. The new monetary policy framework that was adopted following Kuroda's nomination is known as Quantitative and qualitative easing (QQE). It departs from earlier monetary policy not so much in its design as in its implementation (figure 3 ).

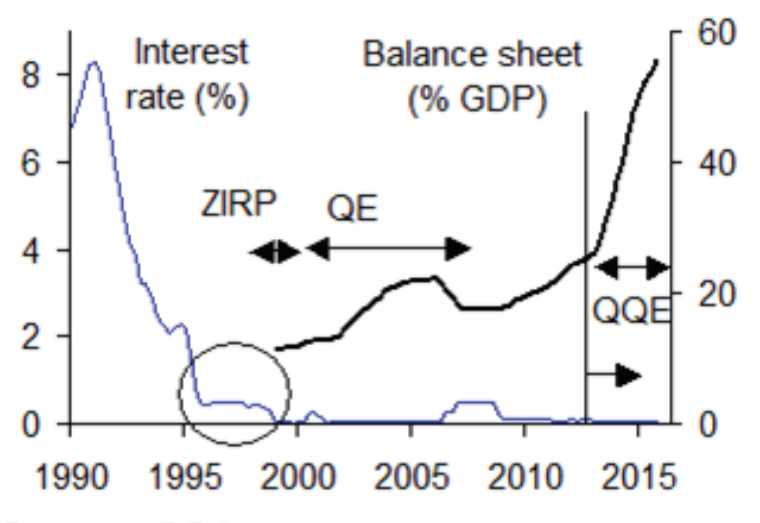

Sources : BOJ.

Figure 3: Conventional and unconventional monetary policy (1990-2016)

A number of reasons explain the cautious approach that had formerly been taken by the central bank in designing monetary policy: the perception that the quantitative expansion policies implemented between 1999 and 2006 (known as Zero Interest Rate Policy or ZIRP then as Quantitative Easing or QE) had failed; the conviction that deflation is primarily due to structural factors; and the fear of inflation slippage should more proactive policies be implemented. However, the position that had earlier been held by the Bank of Japan in regards to the limits of non-conventional policy was somewhat at odds with the growing consensus of other central banks (including the Federal Reserve Board and the ECB) as to the benefits of more proactive, non-conventional policies. In contrast to the previous governor, Shirakawa (2012), the position adopted by Kuroda has been more in line with recent research on monetary policy (Blanchard et al. 2012). In a 2014 speech, Kuroda himself quoted Krugman (1998) as well as Eggertsson and Woodford (2003) as theoretical support for his polices: an active quantitative expansion policy can help exit a liquidity trap such as that experienced by Japan since 1998 (Kuroda, 2014).

Very cautiously, the Bank of Japan under Shirakawa implemented a number of measures. Each expansionary decision was usually followed by backtracking and official warnings as to the measure's possible costs and uncertain effectiveness, thus encouraging private investors to form negative expectations. In contrast to his predecessor, Kuroda established a new monetary framework in the aim of doubling the money supply over a two-year period (that is, ending mid-2015) in order to initially achieve a target of $2 \%$ inflation.

The new policy focused on three main channels of monetary policy implementation: reduced long-term interest rates; increased lending and investment in risky assets; and altered expectations for inflation. The first goal was supposed to be achieved through monthly Treasury bond purchases - initially, $6 \%$ of GDP, though this was raised to 7\% in 2014 - and purchases of risky securities (index funds or the portfolio of real estate securities). Interest rate reductions were expected to reinforce the second transmission channel, which was supposed to lead to increased lending and growth and contribute to the return to a higher potential level of output. Finally, evolving expectations regarding inflation would indirectly result in lower real interest rates and thus stimulate investment; more directly, it was also expected to prompt more rapid inflation.

\subsection{Fiscal STIMULUS AND FISCAL CONSOLIDATION}

The aim of fiscal policy under Abenomics is to achieve "flexibility" - a potentially ambiguous balance between fiscal consolidation and fiscal stimulus. One key measure of fiscal consolidation was the increase in the consumption tax. This was implemented in April 2014 following a number of stimulus packages to buffer the recessive impact of the tax hike over the course of 2013. The four annual budgets passed between 2013 and 2016 also contained indications as to the direction of public finances. Fiscal policy has been the subject of much debate among those who wish to maintain, delay or cancel the scheduled increase in the consumption tax. Abe's government has also maintained the commitments made by previous governments to halve the primary deficit between 2010 and 2015 and achieve a primary surplus by 2020 . 
We shall now discuss the first measures of fiscal consolidation. The increase in the consumption tax was prepared by Abe's predecessor. The October 2012 Social Security law provided that, depending on the behavior of the business cycle over the preceding six months, the consumption tax would be increased from 5 to $8 \%$ in April 2014 and from $8 \%$ to $10 \%$ in October 2015. These two tax increases were expected to respectively yield 1.5 and 1.0 point of GDP in additional tax revenue. The first tax increase was implemented as scheduled but the second increase was twice postponed - first in October 2014 and then again in April 2016 - due to disappointing GDP results. These delays in increasing the consumption tax are further examples of the internal debate between Keynesians and proponents of fiscal orthodoxy. Abe's advisors - Hamada, for example, who drew support from Krugman - have convinced the Prime Minister to prioritize growth and delay efforts to consolidate public finances. Meanwhile, the Ministry of Finance has taken some compensatory savings measures to offset the impact of delaying an increased consumption tax on revenues.
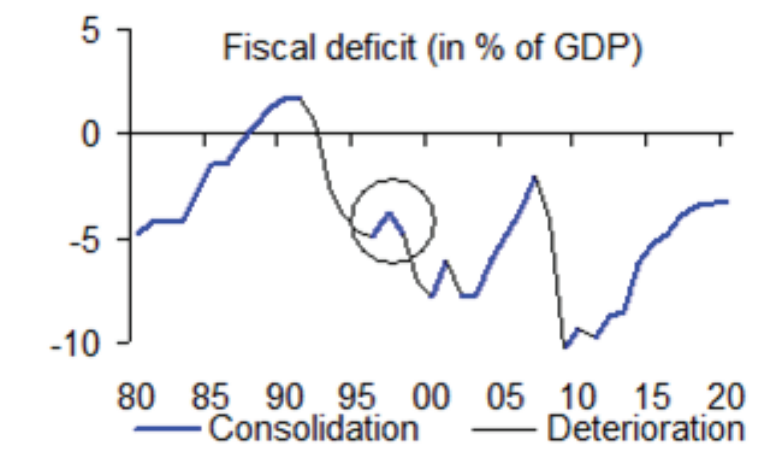

\section{Actual 1980-2015 and projections 2015-20 Sources: IMF WEO.}

Figure 4: Fiscal deficit, actual and projected: 19802020

Four economic support plans containing fiscal stimulus measures were implemented over this period: to restore economic confidence, an initial recovery package in early 2013 was set at $2.1 \%$ of GDP; in 2014, a package set at $1.2 \%$ of GDP was adopted to cushion the impact of the consumption tax hike; a third package, set at $0.7 \%$ of GDP, was enacted in late 2014; finally, a more modest package of $0.5 \%$ of GDP was also implemented. Between 2013 and 2016, the government also presented four annual budgets to Congress. The first two budgets provided for an average 3\% increase in primary expenditure, the third budget contained a smaller, $0.5 \%$ increase and the final budget provided for a larger, $5 \%$ increase.

A pair of traditional (and complementary) analytical tools help one assess the fiscal policy stance of Abenomics: the first consists in studying, on the basis of national accounts, the contribution of consumption and public investment to GDP growth; the second involves analyzing fiscal stimulus in terms of the increase in the structural fiscal balance, calculated by subtracting the cyclical effects of the traditional budget deficit measure. Estimates of structural fiscal balances are taken from the IMF's World Economic Outlook database while those relating to the contribution to growth are derived from Japanese national accounts (Figure 4).

Between 2008 and 2011, Japanese fiscal policy was thus on average expansionary and involved increasingly weak fiscal stimulus. From a stimulus of $4 \%$ of GDP points in 2009 , the stimulus declined to only $0.4 \%$ in 2010-2011, resulting in fiscal contraction in 2012. In its first year, Abenomics reversed the trend of fiscal consolidation, with a larger fiscal stimulus of $0.4 \%$ of GDP. However, this initial fiscal expansion was followed by a fiscal contraction of about $1.3 \%$ of GDP, a level equivalent to the average for 2004-2007. Thus, despite the ambiguity of official discourse regarding "flexibility" and the highly touted stimulus programs, which were widely reported in the press, Abenomics is above all a gradual fiscal consolidation strategy. At the same time, it recognized the importance of public consumption and investment in supporting the business cycle and cushioning the impact of the consumption tax increase, which over three years contributed an average of between 0.2 and 0.1 points of growth, or $4 / 10$ of the total.

Despite the overall stance in favor of consolidation, it is far removed from the levels seen in Europe. One major difference with Europe consists of the horizon for fiscal consolidation: while set at a few years in Europe, the Japanese calendar extends until 2020, thus limiting the recessionary impact of the tax increase. The serial postponement of the second VAT increase is also clearly a device for lengthening the schedule of fiscal consolidation so as not to penalize household consumption.

\subsection{CHOOSING FROM A MENU OF STRUCTURAL REFORMS}

An important objective of Abenomics is to increase the trend of potential growth and partly also to mitigate the impact of demographic decline and the recessive impact of public finance consolidation. In this context, the dominant view in Japan is very similar to that in Europe: increasing potential growth can be achieved through structural reforms, leading to increased productivity growth and a higher contribution of production factors, the development of free trade agreements and business creation. Abenomics thus borrows quite a lot from the standard reform package proposed by previous governments and advocated by academics and international organizations (Figure 5). 


\begin{tabular}{|c|c|c|c|c|}
\hline \multicolumn{5}{|c|}{ Suggested reforms to raise potential growth in Japan* } \\
\hline Measure & $\begin{array}{l}\text { Impact } \\
\text { on GDP }\end{array}$ & $\begin{array}{c}\text { Objective } \\
\text { of Abe }\end{array}$ & $\begin{array}{l}\text { Implem- } \\
\text { entation }\end{array}$ & Sources \\
\hline \multicolumn{5}{|l|}{ Labor market } \\
\hline Female labor participation & 0.25 & yes & limited & JIMF: OECD \\
\hline Flexibility, firing / hiring & $\ldots$ & no & ... & $\ldots$ \\
\hline Immigration & 0.15 & yes & limited & IMF: OECD \\
\hline \multicolumn{5}{|l|}{ Agriculture and trade } \\
\hline Agriculture (direct impact) & 0.03 & yes & gradual & Takatos hi Ito. \\
\hline $\begin{array}{l}\text { Free trade agreements -. } \\
\text { Deregulation }\end{array}$ & 0.30 & yes & gradual & FMI : Adam Posen : CAO. \\
\hline $\begin{array}{l}\text { Special economc zones } \\
\text { Électricity }\end{array}$ & 0.20 & $\begin{array}{l}\text { yes } \\
\text { yes }\end{array}$ & $\begin{array}{l}\text { gradual } \\
\text { limited }\end{array}$ & $\ldots$ \\
\hline Financial support to SME & 0.25 & no & $\ldots$ & IMF \\
\hline $\begin{array}{l}\text { Bus iness climate, gover nance } \\
\text { Total }\end{array}$ & 120 & yes & gradual & Takeo Hoshi. \\
\hline
\end{tabular}

Figure 5: Traditional structural reform packages and Abenomics

These recommendations are echoed by various advisory bodies, including the Council of Economic and Fiscal Policy (CEFP). Beyond these run-of-the-mill reforms, Abenomics also focuses on other measures - increasing female participation rates (rather than immigration), for example, and liberalizing the agricultural sector (agricultural subsidies are higher in Japan than other OECD countries). The government has also considered taking steps to encourage higher labor force participation rates among seniors but its room for maneuver remains limited given that Japan is already in the top tier of OECD countries in this respect.

Reform packages have been introduced almost yearly by the Abe government (most notably in June 2013 and June 2014 for the initial impetus). The measures have been widely discussed within each of the three advisory councils (CEFP for economic policy, CIC for industrial competitiveness, CRR for regulatory reform). Those councils bring together ministers, academics and businessmen (including the CEO of Rakuten, an Internet shopping business, and Lawson, a convenience store franchise chain) but lack labor and consumer representation. Three main features of Abe's method are worth underscoring: international trade is used as a catalyst; efforts are made to balance potentially conflicting objectives and cultivate potentially antagonistic electorates; and policies are associated with timetables and measurable targets, both of which were at least initially enforced.

The decision to join the Trans-Pacific agreement negotiations (TPP) is often presented as a personal choice on the part of Abe. This agreement brings together twelve countries loosely connected by the Pacific Ocean, from the US to some ASEAN countries as well as Australia and Canada. China and Korea are both notably absent from the agreement. Japan earlier failed to join the negotiations in 2010, mainly because of opposition from the farm lobby. The fact that Korea signed a series of trade agreements in close succession with both the United States and the
European Union and the perception that there was a risk that TPP might conclude without Japan convinced the Japanese government of the urgent need to join. Against opposition from the majority of LDP members in Parliament, Abe announced that Japan intended to join the TPP in the course of his first meeting with his American counterpart, Barrack Obama, in early 2013. Contrary to expectations, Japan also took the surprising step of gradually phasing out price controls on rice (though it continued to maintain high tariffs). The TPP was ultimately signed in February 2016 and is currently pending ratification. In addition to the TPP, Japan is also pursuing bilateral and regional trade negotiations with the European Union, China and Korea (a perennially slow moving issue) and four ASEAN countries (RCEP), some of which are part of the TPP. Abe's trade policies are consistent with the pro-international trade position taken by the METI and MOFA ministries, among others. They nonetheless contrast sharply with those favored by most LDP members, who are much more attentive to the demands of their electorate's traditional base.

A second feature of Abe's method consists in the search for political compromise. Although his policies are clearly liberal in inspiration, they are tempered by many exceptions. Three specific cases provide evidence of this. The first relates to agriculture: while Abe's commitment to the TPP led him to turn his back on a segment of the LDP's traditional electoral base, he also vigorously defended five exceptions to the liberalization of agriculture (rice, wheat, beef, dairy products, sugar). This same spirit of compromise is in evidence in what concerns the health care sector, specifically the pharmaceutical industry and distribution networks: while the CEO of the online distributor Rakuten, a member of the Industrial Competitiveness Committee, campaigned for an end to all restrictions on the online marketing of drugs, Abe eventually approved the recommendations of the Ministry of Health, limiting the measure to "products classified without risk", a restrictive notion susceptible to bureaucratic interpretation favoring 
existing stakeholders. A third example can be found in Abe's efforts to leverage his ties to the business world in order to convince large companies to raise wages. His efforts began to bear fruit in 2014, which witnessed a moderate increase in the bonuses paid workers. More significant progress was made in 2015 when, for the first time in over 10 years, companies such as Toyota increased the fixed component of compensation. This increase took place, however, after a long period of stagnation and the policy does not replace institutional mechanisms such as the Shuntō, which for most of the postwar period played a constructive role in fostering cooperation between employers and trade unions (Lechevalier, 2014).

A final characteristic of Abenomics is its recognition of the importance of reforms to monitor indicators. This contrasts with earlier practice, in which targets were set without indicator or calendar. Still, only a third of the initial objectives were quantified and dated. Moreover, in the absence of clear action, some of them seem quite unrealistic.

\section{Short-term impact of Abenomics}

The official outlook for Abenomics as it was initially described by Japanese government and Bank of Japan forecasts contrasts sharply with actual outcomes (Bank of Japan, 2013 and 2015). Japan has neither reached the $2 \%$ inflation target schedule that was to be attained in 2015 nor achieved 2\% growth - the conventional benchmark for all mid-term government forecasts (figure 6). Its results are thus disappointing. A more detailed examination, however, allows for more balanced assessment. In our view, Abenomics achieved the goal of exiting deflation but has fallen short of the more ambitious official inflation target. In the case of growth, meanwhile, the record is considerably more mixed. Complementary assessments of Abenomics can be found in Hausman and Wieland $(2014,2015)$ or, for a critical view from within the central bank, Kiuchi, 2015).

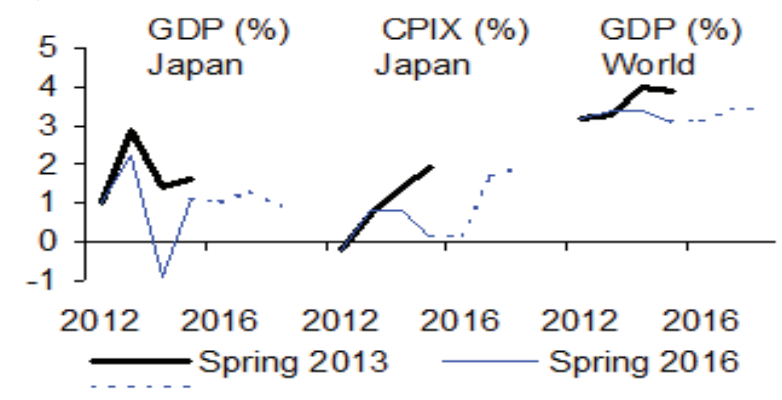

Sources: Bank of Japan, April 2013 and June 2016 outlooks; International Monetary Fund, Spring 2013 and Spring 2016 forecasts. CPIX is core inflation (excluding fresh food). Current projections in dash line.

Figure 6: Abenomics: Initial Prospects and Outcome 2012-2016

\subsection{A tentative EXIT FROM DEFLATION}

Two elements complicate the interpretation of inflation data: the temporary impact of increasing consumption tax on prices and supply shock due to the fall in the price of imported energy. After increasing through mid2014, inflation decelerated in the second half of the year, becoming negative in 2015 and flat in early 2016. The Bank of Japan decided to change its main core inflation indicator, replacing an index excluding fresh food with one that excludes food and energy, similar to the indicator preferred in the United States. Should this be seen as proof that Haruhiko Kuroda failed in his efforts to exit deflation?

For several reasons, that is not our view. Since 2013, Japan has on average experienced a moderate, $0.5 \%$ rate of inflation, compared with a $1 \%$ rate of deflation over the preceding five-year term of Governor Shirakawa. Given measurement bias in inflation, this result remains fragile but the fact that the inflation rate has shifted by nearly one and a half percentage points is not to be dismissed. Besides, inflation targeting should not be understood as dependent upon the monthly realization of a certain level of inflation but rather as a means to providing a stable basis for calibrating inflation expectations. While many biases affect household inflation expectations (the weight of the past, adaptive expectations, upward bias), detailed analysis of household surveys suggests that households now assume a roughly $2 \%$ rate of inflation in the medium term and with lower dispersion, reflecting a better understanding of the objective pursued by the central bank. As measured by the ESP survey, the expectations of professional economists also converged towards higher inflation around $1 \%$ at the horizon of one year. Finally, the deceleration of inflation over the course of 2015 mainly stemmed from the sharp decline in oil prices. When one uses an index that excludes energy, however, the inflationary uptrend is confirmed. From this point of view, the current exit from deflation seems more durable and sustainable than the similar exit that occurred on the eve of the Lehman shock, largely reflecting the temporary impact of rising oil prices (figure 7).

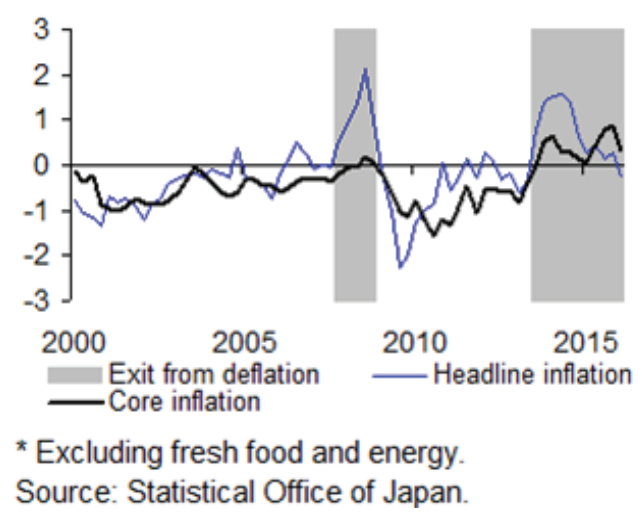

Figure 7: Core Inflation excluding the impact of the VAT (2000-2016) 
Mr. Kuroda seems to have won his bet to lead Japan out of deflation but he has failed in his goal to achieve a $2 \%$ rate of inflation. Indeed, inflation continues to fall short of initially set goals, a fact that in October 2014 led the Bank of Japan to strengthen its program of quantitative expansion with a new component called QQE II, an annual increase of the monetary base from 13 percentage points of GDP to 16 points.

\subsection{AN ERRATIC GROWTH PERFORMANCE}

Over a brief, three year period, economic performance has been quite volatile. This contrasts with the general improvement in some variables such as stock market performance (as measured in terms of Nikkei Index evolution), correction of Yen overvaluation and the continued decline in the unemployment rate, from 4.3 $\%$ at the end of 2012 to $3.1 \%$ at the end of 2015 . Yet it is hard to identify any respect in which these variables strongly impacted corporate investment, export volume, household consumption or, ultimately, the growth of GDP.

Ultimately, the generally good performance of financial indicators such as the stock market and exchange rate (Figure 8 ) only moderately contributed to growth. The two most notable immediate results of Abenomics have been rising stock prices ( $80 \%$ over the period) and a $40 \%$ depreciation of the Yen against the dollar (or 30 $\%$ in terms of real effective exchange rate). However, the weakness of wealth effects in Japan has limited the stock market's impact on consumption. Exchange rate depreciation contributed to an increase in exports but much more slowly than expected. The continued decline in long-term interest rates is evidence that the Bank of Japan's policy has been successful and has contributed to growth in banking credit. In investment, however, the recovery has been much less marked. If the growth in the overall level of activity is less pronounced than might otherwise be expected, this is due to the conflicting forces affecting the main components of domestic and foreign demand.

Financial variables 1990-2016

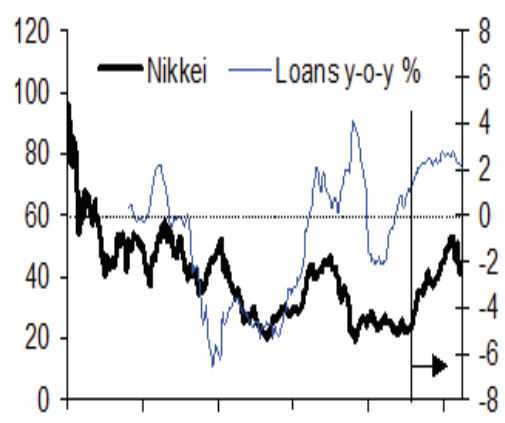

199019952000200520102015

Sources : BOJ; Nikkei Index.

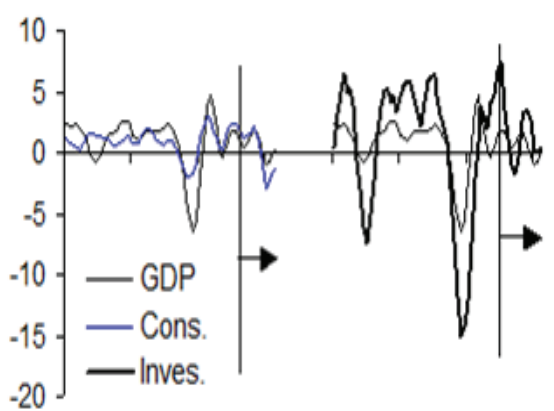

2000200520102015200020052010201 :

\section{${ }^{*}$ Rolling average growth over four quarters.} Sources: CAO.

Figure 9: GDP growth, consumption, and investment (2000-2016)

For its part, GDP growth at first accelerated under the impact of the 2013 fiscal stimulus but subsequently contracted in 2014 due to the consumption tax increase. The resulting slowdown, however, was greater than expected. After a tepid recovery in early 2015, Japan once again experienced a slowdown (figure 9).

The ultimate success of Abenomics will depend on the behavior of the private sector once the monetary and fiscal authorities have established a more predictable macroeconomic framework (low inflation, gradual consolidation of public finances). On the corporate side, the success of Abenomics depends on more concerted action to boost wages and declining corporate savings to increase investment. As for households, the uptick in inflation and rising taxation will contribute to eroding gross disposable income, which makes increasing nominal wages a matter of crucial importance.

When compared to a counterfactual scenario in which past policies were continued, the results of Abenomics have been quite satisfactory. In general, its design and architecture appear sound. There are, however, two caveats. First, Abenomics has fallen short of its original goals and some of these goals have yet to be implemented or progress beyond the stage of good intentions. In what regards outcomes - and this is the second caveat - exiting deflation and boosting growth are both proving far more difficult than expected. In particular, monetary policy is not a magic wand that can immediately solve all problems. Correcting the overvaluation of the exchange rate is not sufficient to boost exports. Increasing the central bank's balance sheet is not sufficient to achieve the inflation target.

Figure 8: Financial Variables (1990-2016) 


\begin{tabular}{|c|c|c|}
\hline \multicolumn{3}{|c|}{ Compa rison of the reform outcome of Koizumi and Abe } \\
\hline & Koizum i / Takenaka (2000-2005) & A be (2012 until now) \\
\hline $\begin{array}{l}\text { Financial } \\
\text { system }\end{array}$ & $\begin{array}{l}\text { Reduction of NPL } 2002-05 \\
\text { Core capital of banks } \\
\text { Priva fsation of Japan Post } 2005 \text { (by 2015) }\end{array}$ & $\begin{array}{l}\text { Stewa rdsh ip Code } 2006 \\
\text { Re forme of GPIF } 2005 \\
\text { Resumption of priva fsation of Japan Post }\end{array}$ \\
\hline Labor market & \begin{tabular}{|l} 
Dispatched Workers Act 2003 \\
No measures for regular workers
\end{tabular} & $\begin{array}{l}\text { Scheduled increase of minimum wages } \\
\text { Few measures for regular workers }\end{array}$ \\
\hline $\begin{array}{l}\text { Free trade } \\
\text { agreement }\end{array}$ & Some bilateral trade agreement & $\begin{array}{l}\text { TPP agreement; EU - Japan } \\
\text { Ongoing discussions RCEP (Chin a-Korea) }\end{array}$ \\
\hline Deregulation & Special economic zones & $\begin{array}{l}\text { Special economic zones } \\
\text { deregulation in health, electricity }\end{array}$ \\
\hline $\begin{array}{l}\text { Public finan ce } \\
\text { susta inability }\end{array}$ & $\begin{array}{l}\text { Trinity re form (local government) } 2003 \\
\text { Pension reform } 2004\end{array}$ & $\begin{array}{l}\text { Increase of VAT } 2014 \\
\text { Reduction of corporate tax (by 2018) }\end{array}$ \\
\hline Agriculture & Limited reforms... then re versal after Koizumi & $\begin{array}{l}\text { Within the TPP, trade liberalization with some } \\
\text { excep fons. Reform of ru ral cooperatives. }\end{array}$ \\
\hline Immigration & & Limited reform on immigra fion \\
\hline
\end{tabular}

Figure 10: Comparing Abe and Koizumi's structural reforms

\section{Why Abenomics may fall}

In the preceding sections, we have argued that current mainstream judgments regarding Abenomics are partly based on preconceived ideas and tend to under-evaluate its benefits. In this section, we would like to emphasize the risk that Abenomics may nevertheless fail in the middle term. Our argument is not a classical criticism focusing on an alleged lack of structural reforms. To the contrary, we show, not only that there has been significant structural reform in Japan over the last two decades, but also that the policies adopted by Abe are in keeping with earlier programs in this respect. Yet a classical program of structural reforms is incapable of resolving the structural weakness of the Japanese economy; Abenomics has failed to adequately attend to these weaknesses or adopt appropriate measures in response to them. We argue that the ultimate success of Abenomics will greatly depend on the ability of the Japanese government to jointly define a sustainable growth model and viable social compromise.

\subsection{THE LIMITS OF STRUCTURAL REFORMS}

It is often claimed that growth has failed to recover in Japan because the "third arrow" never really flew (see for example, Katz, 2014). Yet, much like his predecessor, Koizumi, whose legacy is itself disputed (Mulgan, 2013; Hoshi and Kashyap, 2011; Hoshi, 2013), Abe has implemented quite a few structural reforms (Figure 10). While ours is a generally positive evaluation of structural reform design in Abenomics, there have been some exceptions and strategic shortcomings. Contrary to some of his predecessors, Abe's administration has continued to unambiguously pursue the liberalization process. Abe's personal involvement in some areas such as trade policy and agricultural reform cannot be denied. At the same time, the fate of the Trans-Pacific Partnership is now in question, with the newly elected president of the U.S. signaling his intention to withdraw from the accord. This illustrates the fragility of a reform agenda in which trade policy serves as a catalyst since a portion of the benefits ultimately depend upon Japan's trade partners.

In addition to the issue of trade policy, the structural reform agenda has also proven limited in terms of commitment, implementation and design. In some ways, the sheer accumulation of structural measures suggests that catalogs prepared by previous governments, whether LDP or DPJ, have merely been recycled. This apparent policy overlap may be accounted for by reference to their common origin: reform catalog measures are compiled from lists prepared by the various ministries. Though efforts were made to give them more consistency and impose an implementation calendar, it remains the case that significant portions of the catalog have been inherited from the past. The contribution of Abenomics is, from this point of view, limited.

Another criticism concerns Abe's commitment to some of these reforms and the clarity of his message. A good example is the so-called "womenomics", the name given to the policy aimed at expanding women's role in the economy. Abe regularly reiterates his ambitious target of filling 30\% of leadership positions with Japanese women by 2020 (compared to $9 \%$ today and 20 to 25 $\%$ in most other advanced countries). Yet this goal was initially put forward as early in 2002 and has been kept unchanged despite a lack of significant progress over the course of the intervening ten years. Abe has participated in several forums focusing on promoting female participation in the labor market and has advocated the appointment of women to senior civil servant positions. 
He also appointed a woman, Michiko Hasegawa, as one of NHK's three directors. Yet, in one of her first remarks in this capacity, she stated that the true role of women in Japanese society was to stay at home (The Economist, 2014). There is also a strong disconnect between the Abe government's good intentions and the gender equality policies that have since the mid-1980s been advocated by feminist movements and the Ministry of Health, Welfare and Labor, which call for addressing structural problems such as the lack of balance between work and family life (Arai and Lechevalier, 2005).

What's more, Abenomics sometimes seem designed less to increase productivity than to promote financial performance. A number of measures that have already been implemented have directly benefited financial markets (such as the reform of the government pension fund, the reform of corporate governance and the monetary policies). For all of their merits, these reforms contrast with the dearth of reforms more specifically focused on increasing productivity. Public policies to support innovation are in keeping with past reforms aiming to promote convergence towards the so-called Silicon Valley model (Lechevalier, 2014). It could even be argued that these trends have been reinforced by the establishment of the Industrial Competitiveness Committee (CIC). In contrast to the policies adopted by some other countries in the aftermath of 2008, however, little has been done to change the course of industrial policy (Chang, Andreoni and Kuan, 2014).

A final criticism concerns the Abe government's inaction with respect to social security despite constantly rising inequality. This lacuna in the political agenda sharply contrasts with the proactive stance taken by the government in regards to monetary, fiscal and trade policy. In our view, there are two main reasons for this. The first has to do with the political failure of the DPJ, the center-right party that ruled from 2009 to 2012. The DPJ emphasized the fight against inequality and the establishment of a new Social Security system to address new risks relating to work and family. The results were poor to say the least. Abe's 2012 electoral strategy thus focused on promoting growth as an alternative to redistribution. More fundamentally, there is little room for social thought in Abe's political project, which is mainly oriented towards foreign policy and restoring Japan's standing as major military power. Abe is nevertheless far from the most liberal member of his party and may be considered pragmatic in what concerns socio-economic issues.

\subsection{BeYOND THE STRUCTURAL REFORM VIEW: AN INSTITUTIONALIST PERSPECTIVE}

Despite this commitment to structural reforms, there is a risk that Abenomics may nevertheless fail to restore growth in Japan. The major reason is not that Japan is aging. Standard economics has demonstrated that demography is not the principal driver of growth in modern economies, as Yoshikawa (2014) and others have argued. A supposed lack of innovation - the key factor of growth - is also not a major problem in our view: Japan has largely retained its capacity for innovation despite (or because) of competition from countries like South Korea and China, which in some sectors has indeed prompted it to rapidly catch up. Instead, Japan's major problem is its failure to diffuse (technological and organizational) innovation, a fact demonstrated by the growing productivity gap separating the nation's most productive firms from the rest of the economy (Lechevalier, 2014).

In our view, the major problem facing the long-term strategy embraced by Abenomics is the failure to clearly define the nation's growth model for the next two decades. Defining a growth regime is a complex question and is not entirely up to the government. It is deeply intertwined with the manner in which a social compromise laying out the costs (or duties) and benefits for each member of society is defined (Boyer et al., 2011). Some questions, however, should be addressed by the government: should growth exclusively rely on exports or on internal demand (from consumers and firms)? What balance should be found between corporate investment and household consumption? How is one to define a growth regime characterized by limited negative externalities for the environment of a type that may be described as a green growth?

This leads us to the matter of the sustainability of growth. Although Abenomics is intended to focus on a return of growth, we argue here that it may not address the most relevant issues. From this point of view, the contrast is indeed sharp between the growth strategy of Abenomics and that of the United States, among others, in the aftermath of the 2008 crisis. More generally, the report prepared for the World Bank by a panel chaired by Michael Spence, The Growth report: Strategies for Sustained Growth and Inclusive Development (2008) argues that efforts to promote growth must today address two major issues: sustainability (environment) and distribution (inequality). Recent years have also witnessed a resurgence of interest in industrial policy in North and South America, Europe and Asia, a phenomenon that preceded the 2007-2008 crisis. The idea that the state can and should intervene in the allocation of resources to promote growth has experienced something of a revival (Debanes and Lechevalier, 2014). In our opinion, the state can be central to the re-coordination process that is needed if innovation is to be more efficiently diffused via spillover. The remainder of this section focuses on the two first issues, namely inequality and environmental issues.

The issue of inequality, for its part, has at least two dimensions. The first concerns the wage stagnation that 
has partly contributed to deflation (Canry, Fouquau, and Lechevalier, 2011) (figure 11). From this perspective, it is clear that encouraging firms to raise wages - which seems to be the cornerstone of Abenomics in this areais far from sufficient. If Abenomics is willing to promote a more balanced growth regime in which household consumption is also a key contributor, it should first contribute to the definition of a new wage labor nexus and end the race to the bottom in this area (Boyer and al., 2011). In itself, the consistent decline of unemployment - partly the result of structural considerations - is not sufficient to raise household consumption if it is not also reflected in an overall increase in workers' compensation. Given what is on average very low labor productivity growth, it is often said that there is no room for maneuver in point of wage hikes. This view does not take into account the increasing productivity differential at the corporate level (Ito and Lechevalier, 2009). Any wage policy should take this fact into account and establish institutional rules after the model of the Shuntō's Golden Age (the 1960s and 1970s), when policy provided an efficient institutional setting for wage bargaining, allowing wage hikes to take the productivity differential between firms into account.

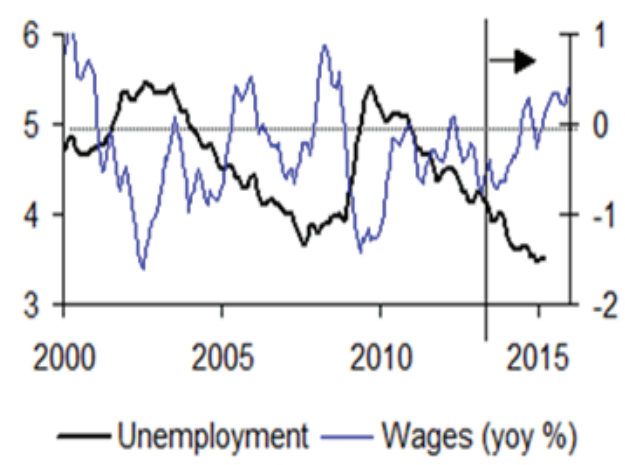

\section{${ }^{\star}$ Contractual wages excluding bonus. Sources : Cabinet Office.}

Figure 11: Unemployment and wage growth

The second issue relating to inequality reflects earlier research (e.g. Lechevalier, 2014, 2015) to the effect that rising inequality in Japan is less the by-product of growth (and the gap between the economy's growth rate and the rate of return on capital, as Piketty has shown) than of the deterioration of labor conditions and the inability of the social protection system to correct this trend. Contrary to a widespread but outdated perception, both the poverty rate and wage inequality have in fact significantly increased in Japan over the past three decades (figure 12).

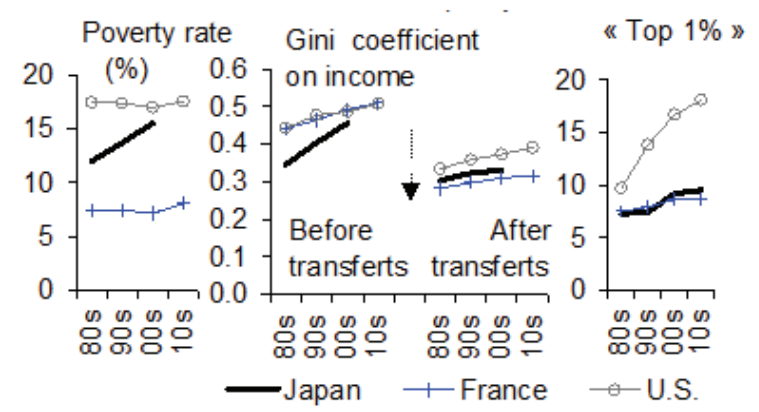

Sources: OECD online database; Top Income Database, Paris School of Economics.

Figure 12: Japan's rising inequalities (1980-2010s)

This should encourage discussion of the possibility of and need for reallocating public resources to social protection (particularly for the least well covered, such as young people), unemployment and the family. This would require reformulating principles of social protection in Japan. In the postwar period, the latter were based on two pillars: families and firms. However, due to a number of developments, this model is no longer viable. In a context of increased competition due to globalization and the conclusion of new international agreements, firms are ever less willing to accept their traditional role in this area, especially in what concerns certain characteristics of the employment system for regular workers (e.g. training in firm specific skills and a relationship based on long-term employment). In these conditions, only the state - together with communities that are often an extension of family ties - seems capable of playing a decisive role. Making this possible requires fiscal reform and this cannot be limited to raising the consumption tax. What is required is deep reform of the tax system in a way that also targets corporate and inheritance taxes.

The essential point here is to understand why inequality may be an impediment to growth in the Japanese context. We base our argument on recent contributions (Ostry, Berg, and Tsangarides, 2014; Stiglitz, 2013; Rajan, 2010; Spence, 2008) showing that standard economics have simultaneously under-estimated the negative impact of inequality on growth and over-estimated its positive impact in terms of incentives. As Dore suggested more than twenty years ago (Dore, 1994), this implies that that there may in fact be no trade-off between efficiency and equality. To us, the most important channel in the Japanese context relates to the risk that the social consensus will be undermined by efforts to adjust to major shocks. Despite its depiction as the ideal-typical consensus society, conflict has been an ever-present feature of post-war Japanese society (Krauss and al., 1984; Eisenstadt and Ben-Ari, 1990). In contemporary 
Japan, there are signs of diverging interests and growing conflict. This may make adjusting to the shocks associated, for example, with the inevitable tax hikes or an aging population (Chiavacci and Hommerich, 2016) particularly difficult and painful.

In the case of environmental issues, one has the impression that the third arrow of Abenomics was conceived and designed as if the nuclear accident at Fukushima never happened (Fukusaku, 2012). The issue here is not merely one of democracy (the Abe government decided to resume operations at some nuclear plants despite opposition from a majority of Japanese citizens). Rather, it is associated with two key questions: Are fossil fuels, coal and oil the only alternatives? Or should the government now explore the prospects for a more energy-efficient model of growth drawing upon a unique energy-mix? As the case of German energy choices illustrates - choices that were partly conditioned by France's decision to retain its nuclear plants and return to highly polluting energies such as coal - these questions do not only concern postFukushima Japan. Japan is today faced with a unique opportunity to become a global leader in energy-saving and renewable energy technologies.

More radically, such a reconsideration of the mode of development would also lead one to challenge the absolute primacy of innovation over other sources of growth. Innovation is, by definition, uncertain. Would it thus be unreasonable to reassign some resources to promote balanced regional development and more inclusive growth? From this perspective, the 2008 Growth report, cited above, offers many insights. Japan is one of a group of countries that possess the technological potential needed to identify and adopt solutions that would be beneficial to the environment without harming growth. The debate here has almost exclusively focused on $\mathrm{CO}^{2}$ emission and global warming. What the Fukushima nuclear accident has taught us is that solutions that are positive from this point of view may not be viable from other perspectives. The discussion here should not be limited to the issue of resuming operations at nuclear plants but should rather include open debate regarding the most desirable energy mix given present (short and longer term) constraints and the potential for Japanese excellence in the area of energy conservation and renewable energy development. As a number of Japanese researchers have argued (Kobayashi, 2015; Fujigaki, 2016), citizen involvement in this area should not be seen as an impediment to growth but rather as a source of incentive if Japan is to make progress towards environmentally responsible growth. From the perspective of industrial policy, Japan is well-positioned to become a global leader in the development and application of such technologies.

\section{Conclusions}

This paper has sought to provide a balanced evaluation of Abenomics that avoids the limitations of most previous assessments, which, as we have noted, sometimes verge on caricature. We oppose explanations that focus on a single factor - for example, those of "irresponsible" economists who believe that everything can be managed via monetary policy as well as those of their "responsible" counterparts who believe that productivity is key.

To the question, "Has Abenomics worked?" our answer is mixed. We argue that Abenomics has used proactive policies to decisively reverse one cause of the Japanese slowdown over the past twenty years and that these actions have now begun to yield results. It should nevertheless be acknowledged that, four years after these policies were first launched, the results have fallen short of targets, especially in regards to price dynamics and GDP growth.

In our view, this should not lead one to conclude that Abenomics is just another failed economic experiment. Abenomics is a very comprehensive economic strategy, especially when one compares it to past efforts in Japan (e.g. Koizumi and his successors) or those undertaken elsewhere in the world in the aftermath of the 2008 crisis (e.g. the inability of European governments and the European Commission to define a comprehensive growth strategy not restricted to austerity measures). To understand this point, one must resist the temptation to regard Abenomics solely in terms of its aggressive monetary policy. Rather, it should be seen as an attempt to render economic policy consistent over a certain timeframe and coordinate different tools. If one takes the "three arrows" metaphor seriously, it becomes clear that the first two arrows are aimed at the short term while the third arrow targets the medium to long term. From the perspective of economic theory, Abenomics seeks to overcome the perennial debate between monetary and real explanations of price dynamics. Contrary to what is often said, Abenomics has also addressed productivity issues and attempted to respond to them.

In contrast to such influential economists as Hiroshi Yoshikawa (2013) and Ryutaro Kono, we thus do not explain Abenomics' mixed results to date by reference to a structural flaw in its conception but rather by reference to two issues. First, it should be acknowledged that economic theory does not adequately account for the introduction of the first two arrows of Abenomics. For example, standard economics does not suffice to explain why, in a context of labor shortage, wages have not increased or why exports did not rise with the weakening of the Yen. Second - and more importantly - the fact that some areas have exhibited disappointing results 
after four years reflects the action of the third arrow, not the first two. By challenging the de facto illusion that crisis or depression is a condition for implementing economic reform, this arrow sought to provide some freedom for medium and long-term economic policies.

This leads to our second question: "Will Abenomics fail?" Our answer is a tentative "yes". The problem here is not so much the lack of structural reforms - Abe has acted much more aggressively in the area of trade policy than his predecessors - as their limited ability to enhance the nation's growth potential. By their very nature, these reforms are not suitable for addressing two issues that are key to sustainable growth: inequality and the environment. Over the past 30 years, the liberalization of the Japanese economy has gone some way towards improving the functioning of markets. It has also produced some negative side effects - e.g., increased productivity dispersion at the corporate level - that can only be dealt with via re-coordination to encourage spillover in the economy. From this perspective, Abenomics does not offer any convincing answer.

Given the risk that Abenomics will fail, does a credible alternative exist? In our view, the path is extremely narrow. On the one hand, policies inspired by realside explanations of Japanese stagnation and the focus on improving productivity may in the long run come up against the constraints imposed by deteriorating economic conditions. This may lead to further increases in public spending and debt. On the other hand, the DPJ's failure between 2009 and 2012 closed the window of opportunity on undertaking a more ambitious program to address inequality and environmental issues. In this context, the only way for Japan to avoid coming to a dead end in the medium term is to revise the third arrow of Abenomics by incorporating these issues. 
References

Accessibility to all electronic documents was verified on the $25^{\text {th }}$ of September 2016

Abe, S., Towards a Beautiful Country: My Vision For Japan, Vertical Editions, 2007.

Arai M. and S. Lechevalier "The Inequalities between Men and Women in the Japanese Labour Market. A Regulationist Approach", Economic Science (Keizai Kagaku), Vol. 52 no4, March 2005.

BANK OF JAPAN, "Outlook for Economic Activity and Prices", April 2013.

BANK OF JAPAN, "Outlook for Economic Activity and Prices", July 2016.

Bernanke, B., "Japanese monetary policy : a case of self-induced paralysis", in Ryoichi Mikitani and Adam Posen (eds), Japan's Financial Crisis and Its Parallels to US experience, Washington (DC), Institute for International Economics, 2000.

Bernanke, B., The Courage to Act, New York (NY): W. W. Norton, 2015.

Blanchard, O., D. Romer, M. Spence, and J. Stiglitz (eds), In the Wake of the Crisis, Cambridge (MA): MIT Press, 2012.

Boyer, R., A. Isogai, and H. Uemura (eds), Diversity and Transformations of Asian Capitalisms, London: Routledge, 2011.

Boyer, R. and Saillard, Y., Regulation Theory: The State of the Art, London: Routledge, 2001.

Canry, N., J. Fouquau, and S. Lechevalier, "Sectoral price dynamics in Japan: a threshold approach", Economics Bulletin, 31 (2), 2011.

Cargill, T. and T. SaKamoto, Japan since 1980, Cambridge: Cambridge University Press, 2008.

Chang, H.J. A. Andreoni, and M. L. Kuna, "International industrial policy experiences and the lessons for the UK", in A. Hughes (ed.), The Future of UK Manufacturing: Scenario Analysis, Financial Markets and Industrial Policy, 2014.

Chiavacci, D. and C. Hommerich (ed.), Social Inequality in Post-Growth Japan: Transformation during Economic and Demographic Stagnation, London: Routledge, 2016.

Debanes, P. and S. Lechevalier (DIR.), "Vers un renouveau de l'État développeur en Asie ?", Critique Internationale, 63, 2014.

Dore, R. "Equality-Efficiency Trade-Offs: Japanese Perceptions And Choices", in M. Aoki and R. Dore (eds) The Japanese Firm. Sources Of Competitive Strength. Oxford: Oxford University Press, 1994, 379-392.
ECONOMIST, THE, "Japanese women and work: Holding back half the nation", March 29th, 2014.

EgGertsson, G. And M. Woodford, "The zero bound on interest rates and optimal monetary policy", Brookings Paper on Economic Activity, 2003.

Eisenstadt, S. And Ben-Ari, E. (eds) Japanese Models Of Conflict Resolution, London and New York (NY): Kegan Paul, 1990.

FuJIGaKi Y. (dir.), Lessons From Fukushima: Japanese Case Studies on Science, Technology and Society, Springer International Publishing AG, 2016.

FuKUSAKU, Y., "Exploring renewable energy systems in post-Fukushima Japan: a new innovation model?", Research note series of the Fondation France Japon de l'EHESS 2012. (http://ffj.ehess.fr/index/article/295/ exploring-renewable-energy-systems-in-post-fukushimajapan-a-new-innovation-model.html)

Hamada, K., "Policymaking in deflationary Japan", The Japanese Economic Review, 55 (3), 2004.

Hausman J. and J. Wieland, "Abenomics: an update", 2015; Hausman J. and J. Wieland, "Abenomics : preliminary analysis and outlook ", 2014.

Hayashi, F., et E. Prescott, "The 1990s in Japan: A Lost Decade", Review of Economic Dynamics, 5, 2002, 206-235.

Hoshi, T. and A. Kashyap, "Why Did Japan Stop Growing?", National Institute for Research Advancement (NIRA), 2011.

Hoshi, T., « Will Abenomics restore Japan's growth ? », Stanford University, NBER and TCER, 2013.

Ito, K. and S. Lechevalier, "The evolution of the productivity dispersion of firms. A reevaluation of its determinants in the case of Japan", Review of World Economics, 145 (3), 2009.

Ito, T. And F. Mishrin, "Two decades of monetary policy and the deflation problem", NBER Working Paper, $\mathrm{n}^{\circ} 10878,2004$.

Iто, T., "We are all QE-sians now", Bank of Japan, IMES Discussion Paper Series, 14-E-07, 2014.

Ito, T. And C.-H. Hahn, (eds.), The Rise of China and Structural Changes in Korea and Asia, Northampton (MA): Edward Elgar, 2010.

Ito, T., H. Patrick and D. Weinstein (ed.), Reviving Japan's Economy: Problems and Prescriptions, Cambridge (MA), MIT Press, 2005. 
Katz, R. "Vodoo Abenomics: Japan's Failed Comeback Plan", Foreign Affairs, July/August, 2014.

KIUChI, T. "Revisiting QQE", Speech at the Capital Markets Research Institute, Bank of Japan, December 2015.

Koo, R., Balance Sheet Recession: Japan's Struggle with Uncharted Economics and its Global Implications, New York (NY), Wiley, 2003.

Krauss, E., Rohlen, T. and Steinhoff, P. (dir.) Conflict In Japan. Hawaii, HI: University Of Hawaii Press, 1984.

Krugman, P., "It's baaack: Japan's slump and the return of the liquidity trap", Brookings Paper of Economic Activity, 2, 1998.

Krugman, P., "Japan the model", The New York Times, May 23, 2013.

KurodA, H., "The practice and theory of unconventonal monetary policy ", speech at the congress of the International Economic Association, Bank of Japan, 2014.

Lechevalier, S. (ed.), The Great Transformation of Japanese Capitalism, London: Routledge, 2014.

Lechevalier, S. (ed.), "Globalization and labor market outcomes : de-industrialization, job security, and wage Inequalities", Review of World Economics 151 (3), 2015.

LecheVAlier, S., AND B. Monfort, Leçons de l'expérience japonaise. Vers une autre politique économique?, Collection du CEPREMAP $\mathrm{n}^{\circ} 41$, Editions Rue d'Ulm, 2016.

Lincoln, E., Arthritic Japan: The Slow Pace of Economic Reform, Washington (DC), Brookings Institution Press, 2001.

Lucken, M., Bayard-SAKaI, A., AND Lozerand, E., Japan's Postwar, London: Routledge, 2014.

Motonishi, T. and H. Yoshikawa, "Causes of the long stagnation of Japan during the 1990s : financial or real ?", Journal of the Japanese and International Economies, 3 (4), 1999.

Mulgan, A. G. Japan's Failed Revolution: Koizumi and the Politics of Economic Reform,Canberra: ANU Press, 2013.

Ostry, J., A. Berg, And C. Tsangarides, "Redistribution, Inequality, and Growth", International Monetary Fund, Staff Discussion Note, 2014.

Rajan, R., Fault Lines: How Hidden Fractures Still Threaten the World Economy, Princeton (NJ): Princeton University Press, 2010.

ShIRAKAWA, M. "Sustainability of public debt: preconditions for the stability of the financial system and prices ", Remarks at the Banque de France Financial Stability Review Launch Event in Washington D.C., Bank of Japan, April 2012.

Spence, M. (ed.), The Growth Report: Strategies for Sustained Growth and Inclusive Development, Washington (DC), The International Bank for Reconstruction and Development / The World Bank, 2008 .

Stiglitz, J., The Price of Inequality, New York (NY): W.W. Norton, 2013.

Tiberghien, Y., "Thirty years of neoliberal reforms in Japan", in S. Lechevalier, The Great Transformation of Japanese Capitalism, London: Routledge, 2014.

UEDA, K., "The effectiveness of non-traditional monetary policy measures: the case of the Bank of Japan", The Japanese Economic Review, 63 (1), 2012.

WAKATABE, M., Japan's Great Stagnation and Abenomics, NY (NY): Palgrave-Macmillan, 2015.

Yoshikawa, H., Japan's Lost Decade, Tokyo: LTCB International Library/International House of Japan, 2002.

Yoshikawa, H., Defureshon, Nippon no manse byo no zenbo o kaimei suru (Deflation, explaining Japan's chronic disease), Tokyo: Nikkei Publishing Inc., 2013. 